\title{
PENENTUAN KANDUNGAN TOTAL FLAVONOID DAN TOTAL FENOL DARI AKAR KERSEN (Mutingia calabura) SERTA AKTIVITASNYA SEBAGAI ANTIOKSIDAN
}

\author{
M. R. M. Senet, I G. M. A. P. Raharja, I K.T. Darma, K. T. Prastakarini, N. M. A. Dewi, dan
}

\author{
I M. O. A. Parwata
}

\author{
Program Studi Kimia FMIPA Universitas Udayana, Bukit Jimbaran, Bali \\ *Email: ratihmettaswari@yahoo.co.id
}

\begin{abstract}
ABSTRAK
Penelitian ini bertujuan untuk mengetahui kadar fenol dan flavonoid total dari ekstrak akar kersen serta aktivitas antioksidannya. Hasil ekstraksi $1 \mathrm{~kg}$ akar kersen menghasilkan ekstrak etanol $(30,56 \mathrm{~g})$, kloroform $(6,52 \mathrm{~g})$, etilasetat $(6,1 \mathrm{~g})$, n-butanol $(3,21 \mathrm{~g})$ dan air $(4,65 \mathrm{~g})$. Penapisan fitokimia menunjukkan ekstrak yang positif flavonoid adalah ekstrak air, kloroform, etanol dan etil asetatsedangkankelimaekstrak tersebut positif mengandung polifenol. Ekstrak etanol, n-butanol, kloroform, etil asetat, dan air memiliki kandungan total fenol berturut-turut yaitu 12,62\%, 3,81\%, $6,12 \%, 8,75 \%$, dan $11,93 \%$. Kandungan flavonoid pada ekstrak etanol, kloroform, etil asetat, dan air berturut-turut yaitu $0,22 \%, 0,05 \%, 0,12 \%$, dan $0,03 \%$. Aktivitas antioksidan pada ekstrak etanol diukur dengan metode DPPH dan dinyatakan dengan nilai $\mathrm{IC}_{50}$ sebesar $36,44 \mathrm{ppm}$
\end{abstract}

Kata Kunci: akar kersen, Muntingia calabura, antioksidan, total fenol, total flavonoid

\section{ABSTRACT}

This study aimed to know the content of total phenol, total flavonoids and the antioxidant activity of kersen root extracts. Extraction of $1 \mathrm{~kg}$ kersen root with five different solvents gained five concentrated extracts of ethanol (30.56 g), chloroform (6.52 g), ethyl acetate $(6.1 \mathrm{~g})$, n-buthanol (3.21 g) andwater $(4.65 \mathrm{~g})$. Phytochemical testrevealed that all of this extracts contained phenolic compound but only water, chloroform, ethanol, and ethyl acetate extracts contained flavonoids. The total phenol content of ethanol, n-butanol, chloroform, ethyl acetate and water extracst were of $12.62 \%, 3.81 \%$, $6.12 \%, 8.75 \%$, and $11.93 \%$, respectively. The total flavonoidof ethanol, chloroform, ethyl acetate and water were $0.22 \%, 0.05 \%, 0.12 \%$ and $0.03 \%$, respectively. The antioxidant activity of extract ethanol measured using DPPH method which represented as $\mathrm{IC}_{50}$ was found to be $36.44 \mathrm{ppm}$.

Keywords: antioxidant, kersen root, Muntigia calabura, flavonoids total, phenol total

\section{PENDAHULUAN}

Antioksidan dalam dunia kesehatan dipercaya sebagai salah satu senyawa yang dapat mencegah berbagai jenis penyakit,akibat kemampuannya dalam menetralkan radikal bebas (Rauf, 2015).Kebutuhan masyrakatakan antioksidan memunculkan banyak produk berlebel antioksidan yang dijual dipasaran, namun produk-produk tersebut sering kali dijual dengan harga tinggi yang tidak terjangkau oleh daya beli semua kalangan masyarakat. Oleh karena itu, diperlukanlah antioksidan alternatif yang berasal dari tumbuhan, dan salah satu tumbuhan yang mengandung antioksidan dan dapat dimanfaatkan sebagai obat adalah tumbuhan Kersen (Muntingia calabura).
Kersen (Muntingia calabura) merupakan tanaman yang kerap ditemui di pinggir jalan sebagai tanaman perindang. Tanaman ini dinyatakan memiliki manfaat yang tinggi sebagai tanaman obat. Hal ini didukung oleh beberapa penelitian pada kulit batang, buah maupun daun kersen yang dinyatakan mengandung senyawa protein, flavonoid, asam askorbat, polifenol, dan alfatokoferol (Azmathulla dkk., 2015), sedangkan pada akar buah kersen itu sendiri diketahui pula mengandung senyawa flavonoid (Kaneda dkk., 1991)

Flavonoid sebagai antioksidan sudah tidak diragukan lagi manfaatnya Senyawa ini dipercaya dapat bertindak sebagai antioksidan karena dapat memberikan atom hidrogen secara cepat ke senyawa radikal atau 
mengubahnya dalam bentuk yang lebih stabil. Flavonoid dapat memberikan efek antioksidan dengan cara mencegah terbentuknya ROS, langsung menangkap ROS, melindungi antioksidan lipofilik dan merangsang terjadinya peningkatan anti-oksidan enzimatik (Markham, 1988).

Kandungan flavonoid sebagai antioksidan telah banyak didukung dalam beberapa penelitian seperti identifikasi senyawa flavonoid dari limbah kulit bawang merah sebagai antioksidan alami (Siti Rahayu, 2015), isolasi flavonoid dan uji antimikroba daun kersen (Arum, 2012) dan isolasi identifikasi serta aktivitas antioksidan senyawa fenolik dari kulit batang kersen (Alista, 2011). Kendati demikian penelitian mengenai akar kersen sebagai antioksidan (Muntingia calabura) masih sangat sedikit dilakukan. Berdasarkan uraian diatas, maka dilakukan penelitian mengenai penentuan kadar total fenolat dan flavonoid dari ekstrak akar (Muntingia calabura) serta aktivitasnya sebagai antioksidan.

\section{MATERI DAN METODE}

\section{Bahan}

Bahan tumbuhan yang digunakan dalam penelitian ini yaitu akar kersen (Muntingia calabura.) yang diperoleh dari kota Denpasar dan telah dilakukan determinasi di UPT Balai Konservasi Tumbuahan Kebun Raya Eka Karya, Tabanan, Bali. Bahan kimia yang digunakan dalam penelitian ini adalah etanol (teknis dan p.a), kloroform (teknis),etil asetat, n-butanol, pereaksi Folin-Ciocateu, aluminium klorida $\left(\mathrm{AlCl}_{3}\right)$, sodium karbonat $\left(\mathrm{Na}_{2} \mathrm{CO}_{3}\right)$,asam galat, natriumhidroksida, kuersetin, DPPH, dan pereaksi fitokimia

\section{Peralatan}

Peralatan yang digunakan dalam penelitian ini adalah blender, ayakan, rotary vacum evaporator, sentrifuge, neraca analitik, pipet mikro, pipet tetes, labu ukur, pipet volume, tabung reaksi, gelas beker dan spektrofotometer UV-vis

\section{Cara Kerja}

\section{Penyiapan Bahan}

Sampel akar kersen (Muntingia calabura L.) yang segar dikumpulkan dari wilayah Ubung. Semua sampel dikumpulkan dalam satu wadah kemudian dicuci hingga bersih. Selanjutnya sampel dipotong kecil- kecil, dikering anginkan tanpa terkena sinar matahari langsung dan dihaluskan dengan menggunakan blender

\section{Ekstraksi danujifitokimiaakar kersen}

Sebanyak $1 \mathrm{~kg}$ serbuk kering akar kersen dimaserasi selama 3 hari dengan menggunakan etanol sebanyak 4 liter. Hasil maserasi selanjutnya disaring sehingga didapatkan filtrat. Filtrat yang diperoleh diuap kanhingga diperoleh ekstrak pekat etanol. Ekstrak pekat etanol yang diperoleh kemudian ditambahkan air dengan perbandingan etanolair (7:3). Campuran tersebut diuapkan pelarut etanolnya sehingga diperoleh ekstrak air yang kemudian dipartisi berturut-turut dengan kloroform, etil asetat dan n- butanol. Masingmasing ekstrak yang diperoleh dipekatkan dengan menggunakan vacum rotary evaporator dan selanjutnya dilakukan uji fitokimia dengan metode Harborne (1987) meliputi uji flavonoid, uji saponin, uji steroid, uji terpenoid,uji alkaloid danuji polifenol. Ekstrak yang positif flavonoid dan polifenol dilanjutkan dengan pengukuran kadar total fenol dan total flavonoid.

\section{Penentuan kandungan fenol total}

Penentuan kandungan fenol total dilakukan dengan metode Diaz (2012) dengan sedikit modifikasi. Sebanyak $0,5 \mathrm{~g}$ ekstrak (ekstrakkloroform, etilasetat, n-butanol, air, danetanol) dilarutkan kedalam labu ukur $5 \mathrm{ml}$ hingga didapat konsentrasi $100 \mathrm{mg} / \mathrm{ml}$. Selanjutnya dipipet $0,5 \mathrm{ml}$ ekstrak $100 \mathrm{mg} / \mathrm{ml}$ dan dilarutkan kedalam labu $5 \mathrm{ml}$ hingga didapat konsentrasi $10 \mathrm{mg} / \mathrm{ml}$. Ekstrak sebanyak $0,5 \mathrm{ml}$ selanjutnya direaksikan dengan $0,5 \mathrm{~mL}$ reagen Folin-Ciocalteu, kemudian diinkubasi pada suhu kamar selama 15 menit. Sodium karbonat $4 \mathrm{~mL}$ ditambahkan dan diinkubasi kembali selama 30 menit. Absorbansi dibaca dengan spektroskopi UVvis pada $\lambda 760 \mathrm{~nm}$. Asam galat dengan konsentrasi $50-300 \mu \mathrm{g} / \mathrm{mL}$ dibuat sebagai kurvaka librasi. Absorbansi sampel di interpolasi kedalam persamaan regresi linear padakurva standar. Ekstrak dengan kandungan total fenol tertinggi kemudian dilanjutkan pada tahap pengujian nilai antioksidan $\left(\mathrm{IC}_{50}\right)$.

\section{Penentuan kandungan flavonoid total}

Kandungan total flavonoid ditentukan dengan metode aluminium klorida dan 
kuersetin sebagai standar. Sebanyak 0,1 gram ekstrak selanjutnya dilarutkan ke dalam labu ukur $5 \mathrm{ml}$ menggunakan etanol $50 \%$ dan disaring. Sebanyak $2 \mathrm{ml}$ ekstrak dipipet dan ditambahkan sebanyak $2 \mathrm{ml}$ etanol $50 \%$. Ekstrak tersebut dimasukkan ke dalam tabung reaksi kemudian ditambahkan $4 \mathrm{ml}$ larutan $\mathrm{AlCl}_{3}$. Larutan selanjutnya dikocok hingga homogen dan didiamkan selama 30 menit. Pengukuran absorbansi dilakukan pada panjang gelombang $415 \mathrm{~nm}$ (Chang dan Wen., 2002) Standar kuersetin dibuat pada konsentrasi 0-100 ppm. Absorbansi sampel di interpolasi ke dalam persamaan regresi linear pada kurva standar. Ekstrak dengan kandungan total flavonoid tertinggi kemudian dilanjutkan padat ahap pengujian nilai antioksidan $\left(\mathrm{IC}_{50}\right)$.

\section{Uji Aktivitas Antioksidan}

Uji aktivitas antioksidan pada akar kersen dilakukan dengan metode Blois (1958) dengan sedikit modifikasi. Sampel (ekstrak etanol) dibuat konsentrasi induk 1000 ppm. Larutan induk ekstrak etanolakar kersendipipet sebanyak $250 \mu \mathrm{L}, 500 \mu \mathrm{L}$, dan $1000 \mu \mathrm{L}$ kemudian dimasukkan ke dalam labu ukur 10 $\mathrm{mL}$ dan di encerkan dengan metanol sampai tanda batas sehingga di dapatkan larutan ekstrak akar kersen dengan konsentrasi 25, 50 dan 100 ppm (Hany, 2016). Larutan uji ekstrak etanoldengan berbagai konsentrasi, masingmasing dipipet sebanyak $2,0 \mathrm{~mL}$ dan ditambahkan 2,0 $\mathrm{mL}$ larutan DPPH. Selanjutnya, larutan tersebut dihomogenkan dengan vortex dan di inkubasi dalam ruang gelap selama 30 menit. Serapan diukur dengan spektrofotometer UV-VIS pada panjang gelombang $517 \mathrm{~nm}$.

\section{HASIL DAN PEMBAHASAN Perolehan Ekstrak Akar Kersen}

Metode ekstraksi yang digunakan pada tahap ini adalah metode maserasi dan partisi. Maserasi yaitu proses pengekstrakan simplisia dengan cara perendaman menggunakan pelarut dengan beberapa kali pengadukan pada temperatur ruang (Djarwis, 2004). Ekstraksi sebanyak $1 \mathrm{~kg}$ serbuk akar kersen dengan 4 liter etanol selama 3 x 24 jam, dihasilkan ekstrak sebanyak 30,56 gram. Selanjutnya kedalam ekstrak pekat etanol dicampurkan air dengan perbandingan (7:3) dan dilakukan penguapan pada etanol sehingga di dapatkan ekstrak air sebanyak 23,75 gram. Ekstrak tersebut selanjutnya dipartisi dengan pelarut yang berbeda kepolarannya yakni pada pelarut kloroform, etil asetat dan n-butanol untuk menarik senyawa aktif pada ekstrak (like dissolve like). Berdasarkan hasil partisi tersebut, maka didapatkan fraksi kloroform 6,52 gram, fraksi etil asetat 6,1 gram, fraksi nbutanol 3,21 gram dan fraksi ekstrak air (setelah dipartisi) sebanyak 4,65 gram.

\section{Skrining Fitokimia Akar Kersen}

Penapisan fitokimia dilakukan untuk mengetahui adanya senyawa metabolit sekunder yang terdapat dalam komponen akar kersen. Uji fitokimia dilakukan menggunakan pereaksi spesifik sesuai dengan metode uji fitokimia Harborne (1987). Hasil penapisan fitokimia dapat dilihat padaTabel 1 .

Ujipolifenol menunjukan hasil bahwa semua fraksi positif polifenol dengan adaya reaksi kompleks yang terbentuk antara $\mathrm{FeCl}_{3}$ dan sampel sehingga terjadi perubahan warna fraksi menjadi hijau hingga hitam.

Padauji terpenoid dan steroid, ekstrak n-butanol, air, etanol, dan kloroform positif mengandung terpenoid sedangkan ekstraketil asetat positif mengandung steroid. Hal ini didukung dengan adanya perubahan warna hijau pada ekstrak n-butanol, air, etanol, dan kloroform sedangkan merah pada ekstrak etil asetat. Adanya perubahan warna pada uji steroid/terpenoid terjadi akibat adanya oksidasi pada senyawa melalui pembentukan ikatan terkonjugasi (Setyowati, 2014), sedangkan pada semua ekstrak memberikan hasil negatif pada uji alkaloid dengan tidak adanya endapan dengan pereaksi Dragendroff.

Uji saponin menunjukkan hasil positif pada fraksi n-butanol dan air yang ditunjukkan dengan munculnya busa stabil setelah penambahan $\mathrm{HCl}$ yang menunjukkan adanya glikosida yang memiliki kemampuan membentuk buih dalam air yang terhidrolisis menjadi glukosa dan senyawa lainnya (Setyowatidkk, 2014).

Uji fitokimia flavonoid dilakukan dengan dua pereaksi berbeda yaitu uji wilsaster $(\mathrm{Mg}-\mathrm{HCl})$ dan $\mathrm{NaOH}$ yang memberikan warna yang spesifik untuk tiap golongan tertentu (Harbourne, 1987). Hasil uji kelima ekstrak diketahui bahwa ekstrak yang positif flavonoid adalah ekstrak air, kloroform, etanol dan etil. 
Tabel 1. Hasil Penapisan Fitokimia

\begin{tabular}{lcccccccc}
\hline \multicolumn{1}{c}{ Fraksi } & Terpenoid & Steroid & \multicolumn{2}{c}{ Flavonoid } & Polifenol & Alkaloid & Saponin \\
\cline { 3 - 7 } & & & $\begin{array}{c}\text { Uji } \\
\text { wilsaster }\end{array}$ & $\mathrm{NaOH}$ & & & \\
\hline n-butanol & + & - & - & - & + & - & + \\
Air & + & - & + & + & + & - & + \\
Etanol & + & - & + & + & + & - & - \\
Etilasetat & - & + & + & + & + & - & - \\
Kloroform & + & - & + & + & + & - & - \\
\hline \multicolumn{2}{l}{ Keterangan : + : positif } \\
& - : negatif & & & & & &
\end{tabular}

asetat dengan adanya perubahan warna yang disesuaikan dengan literatur. Ekstrak yang positif flavonoid dan fenolik selanjutnya ditentukan kandungan total fenol dan total flavonoidnya

\section{Uji Fenol Total}

Masing-masing ekstrak yang positif mengandung fenol pada uji skrinning, selanjutnya diuji kandungan total fenolnya. Pengukuran total fenol digunakan dengan metode Folin-Ciocalteu yang berdasarkan kekuatan mereduksi dari gugus hidroksi fenol dengan menggunakan standar asam galat. Asam galat dipilih karena merupakan substansi yang murni dan stabil. Semua senyawa fenolik termasuk fenol sederhana dapat bereaksi dengan reagen Folin-Ciocalteu walaupun bukan penangkap radikal efektif. Adanya inti aromatis pada senyawa fenolik dapat mereduksi fosfomolibdat fosfotungstat menjadi molybdenum tungsten. Senyawa fenolik hanya bereaksi dengan reagen Folin-Ciocalteu dalam suasana basa agar terjadi disosiasi proton pada senyawa fenolik menjadi ion fenolat (Ukieyanna, 2012). Reaksi fenol dan FolinCiocalteu akan terlihat dari adanya warna kuning dan dengan menambahkan sodium karbonat akan memberikan warna biru. Semakin biru larutan menunjukkan semakin tingginya absorbansi. Hasil pengukuran total fenol dipaparkan pada Tabel 2.

Berdasarkan Tabel 2 diketahui bahwa ekstrak etanol memiliki kandungan total fenol terbesar dengan nilai $12,62 \%$ sedangkan ekstrak nbutanol memiliki nilai kandungan total fenol terendah yakni $3,81 \%$.

\section{Uji Flavonoid Total}

Ekstrak yang positif mengandung flavonoid pada uji skrinning, selanjutnya diuji kandungan total fenolnya.pengukuran pada total flavonoid digunakan dengan prinsip $\mathrm{AlCl}_{3}$ yang akan membentuk kompleks karena memiliki C-4 gugus keto lalu dengan C-3 atau $\mathrm{C}-5$ gugus hidroksil yang bertetangga sehingga terjadi pergeseran panjang gelombang ke arah visible (nampak) yang terlihat dari warna kuning pada larutan (Ukieyanna, 2012). Pada pengukuran total flavonoid dilakukan pembuatan standar kuersetin sebagai pembanding. Kuersetin dipilih karena merupakan salah satu golongan flavonoid (flavonol). Hasil pengukuran flavonoid total dipaparkan pada Tabel 3.

Tabel 2 Hasil Pengukuran Fenol Total

\begin{tabular}{lcccccc}
\hline \multirow{2}{*}{$\begin{array}{c}\text { Kode } \\
\text { sampel }\end{array}$} & $\begin{array}{c}\text { Berat } \\
\text { Sampel }\end{array}$ & $\begin{array}{c}\text { Konsentrasi } \\
\text { sampel }\end{array}$ & Abs & $\begin{array}{c}\text { Konsentrasi (x) } \\
(\mathrm{mg} / \mathrm{L})\end{array}$ & Pengenceran & Kadar GAE \\
\cline { 2 - 3 } \cline { 7 - 8 } & $\mathrm{mg}$ & $\mathrm{mg} / 5 \mathrm{~mL}$ & & & & $\%$ \\
\hline Etanol & 51,40 & 10,28 & 0,89 & 129,77 & 10 & 12,62 \\
n-butanol & 52,80 & 10,56 & 0,34 & 40,26 & 10 & 3,81 \\
kloroform & 50,80 & 10.16 & 0,47 & 62,19 & 10 & 6,12 \\
etil asetat & 51,50 & 10,30 & 0,65 & 90,10 & 10 & 8,75 \\
Air & 51,20 & 10,24 & 0,85 & 122,19 & 10 & 11,93 \\
\hline
\end{tabular}

Keterangan : GAE : Galic Acid Equivalent 
Tabel 3. Hasil Pengukuran Flavonoid Total

\begin{tabular}{|c|c|c|c|c|c|c|}
\hline \multirow[t]{2}{*}{$\begin{array}{l}\text { Kode } \\
\text { sampel }\end{array}$} & $\begin{array}{c}\text { Berat } \\
\text { Sampel }\end{array}$ & $\begin{array}{c}\text { Konsentrasi } \\
\text { sampel }\end{array}$ & Abs & \multirow[t]{2}{*}{$\begin{array}{l}\text { Konsentrasi (x) } \\
\quad(\mathrm{mg} / \mathrm{L})\end{array}$} & \multirow{2}{*}{ Pengenceran } & $\begin{array}{c}\text { Kadar } \\
\text { Kuersetin }\end{array}$ \\
\hline & $\mathrm{mg}$ & $\mathrm{mg} / 5 \mathrm{~mL}$ & & & & $\% \mathrm{QE}$ \\
\hline Etanol & 100 & 20 & 0,83 & 22,19 & 2 & 0,22 \\
\hline Kloroform & 100 & 20 & 0,20 & 4,57 & 2 & 0,05 \\
\hline etil asetat & 100 & 20 & 0,46 & 11,92 & 2 & 0,12 \\
\hline Air & 100 & 20 & 0,15 & 3,35 & 2 & 0,03 \\
\hline
\end{tabular}

Keterangan : QE : Quarcetin Equivalent

Berdasarkan Tabel 3 diketahui bahwa ekstrak etanol memiliki kandungan flavonoid total terbesar yaitu $0,22 \%$ sedangkan kandungan flavonoid terendah terdapat pada ekstrak air dengan nilai yaitu $0,03 \%$ Ekstrak dengan kandungan total flavonoid tertinggi kemudian dilanjutkan pada tahap pengujian nilai antioksidan $\left(\mathrm{IC}_{50}\right)$.

\section{Penentuan Antioksidan dengan Metode DPPH}

Pengujian aktivitas antioksidan dilakukan sesuai metode Blois (1958) dengan melihat absorbansi yang diukur pada panjang gelombang $517 \mathrm{~nm}$. Uji aktivitas antioksidan dilakukan terhadap ekstrak etanol yang memiliki nilai kandungan fenol dan flavonoid total terbesar dari kelima ekstrak. Adanya aktivitas antioksidan pada ekstraketanol secara kasat mata dapat dilihat dari peluruhan warna DPPH yang sebanding dengan adanya penurunan absorbansi pada peningkatan konsentrasi sampel. Hasil analisis antioksidan dapat dilihat pada Tabel 4

Berdasarkan Tabel 4, diketahui bahwa ekstrak etanol menunjukkan aktivitas antioksidan yang tergolong sangat kuat dengan nilai $\mathrm{IC}_{50}$ sebesar 36,44 ppm yang artinya pada konsentrasi 36,44 ppm ekstrak etanol dapat menghambat radikal bebas sebesar 50\% (Blois, 1958).
Dari nilai aktivitas antioksidan yang dibandingkan dengan kandungan polifenol dan flavonoid, diduga kuatnya aktivitas antioksidan pada ekstrak etanol didukung oleh senyawa fenol dan flavonoid. Fenol dan flavonoid merupakan salah satu senyawa yang bersifat sebagai antioksidan karena dapat mendonorkan atom hidrogen dari hidroksi pada senyawa radikal sehingga senyawa radikal dapat bersifat lebih stabil. Kemampuan senyawa tersebut sebagai antioksidan didukung oleh beberapa penelitian seperti kuatnya aktivitas isolat flavonoid sebagai antioksidan pada kulit batang gayam (Hany, 2016) dan ekstraksi polifenol biji kakao secara kimiawi sebagai antioksidan (Porbowaseso, 2005).

\section{SIMPULAN DAN SARAN}

\section{Simpulan}

Berdasarkan hasil penelitian yang telah dilakukan maka dapat disimpulkan bahwa ekstrak etanol, n-butanol, kloroform, etil asetat, dan air memiliki kandungan fenol total berturut-turut yaitu $12,62 \%, 3,81 \%, 6,12 \%$, $8,75 \%$, dan $11,93 \%$ sedangkan kandungan flavonoid pada ekstrak etanol, kloroform, etil asetat, dan air berturut-turut yaitu $0,22 \%$, $0,05 \%, 0,12 \%$, dan $0,03 \%$. Nilai aktivitas antioksidan pada ekstrak etanol dinyatakan dengan nilai $\mathrm{IC}_{50}$ sebesar 36,44 ppm yang tergolong sangat kuat.

Tabel 4 Nilai IC $_{50}$ Ekstrak Akar Kersen

\begin{tabular}{ccccccc}
\hline Sampel & Konsentrasi & \multicolumn{2}{c}{ Absorbansi } & Persamaaan & PersenInhibisi & $\mathrm{IC}_{50}$ \\
\cline { 3 - 4 } & $(\mathrm{mg} / \mathrm{ml})$ & Blanko & Sampeluji & linear & & $(\mathrm{ppm})$ \\
\hline Ekstrak etanol & 25 & 0.64 & 0,32 & $\mathrm{Y}=823,25 \mathrm{x}+$ & 50,16 & 36,44 \\
& 50 & & 0,09 & 20 & 86,80 & \\
& 100 & & 0,08 & & 87,11 & \\
\hline
\end{tabular}




\section{Saran}

Adapun hal yang dapat disarankan dari penelitian ini yaitu perlu dilakukan penelitian mengenai isolasi senyawa aktif antioksidan pada ekstrak etanol akar kersen untuk mengidentifikasi senyawa aktif yang berpotensi sebagai antioksidan

\section{UCAPAN TERIMAKASIH}

Penulis mengucapkan terimakasih kepada Dirjen DIKTI atas bantuan dana penelitian yang telah diberikan serta kepada semua pihak yang telah memberikan saran danmasukan dalam penelitian ini.

\section{DAFTAR PUSTAKA}

Alista, M., 2011, Isolasi, Identifikasi dan Uji Aktivitas Antioksidan Senyawa Fenolik dari Kulit Batang Kersen, Skripsi, Program Studi Kimia, Universitas Airlangga, Surabaya.

Anastasia, H., 2016, Uji Aktivitas Antioksidan Senyawa Flavonoid pada Kulit Batang Tumbuhan Gayam (Inocarpus fagiferus Fosb), Jurnal Kimia, 10 (1), 15-22.

Arum, Supartono, dan Sudarmin, 2012, Isolasi dan Uji Daya Antimikroba Ekstrak Daun Kersen (Muntingia calabura), Universitas Negeri Semarang.

Azmathulla, K.Y., Subhas, C.M., and Dinesha, R., 2015, Antioxidant Activity: Root, Leaves, and Fruit Aqueus Extracts of Muntingia calabura, Joutnal of Innovation in Pharmaceuticals and Biological Sciences, India.

Blois, M.S., 1958, Antioxidant determinations by the use of a stable free radical.Nature, 181: 1199- 1200.

Chang C.Y.M. and Wen, 2002, Estimation of Total Flavonoid in Propolis by Two Complymentary Colorimetric Methods, Journal Food DrugAnal, 178-82.

Diaz, P., Jeong, S.C., Lee, S., Khoo, C., and Koyyalamudi, S.R., 2012, Antioxidant and Anti-inflamantory Activities of Selected Medical Plants and Fungi Containing Phenolic and Flavonoid Compounds, Chinese Medicine, 7:26.
Djariws, D., 2004, Teknik Penelitian Kimia Organik Bahan Alam, Workshop Peningkatan Sumber Daya Manusia Penelitian dan Pengelolaan Sumber Daya Hutan yang Berkelanjutan, Pelaksana Kelompok Kimia Organik Bahan Alam Jurusan Kimia FMIPA Universitas Andalas Padang kerjasama dengan Proyek Peningkatan Sumber Daya Manusia DITJEN DIKTI DEPDIKNAS JAKARTA.

Harborne, J. B., 1987, Metode Fitokimia Penuntun Cara Modern Menganalisa Tumbuhan. Diterjemahkan oleh Kokasih Padmawinata, ITB, Bandung.

Kaneda, N., Pezzuto, J.M., Soejarto, D.D., Kinghorn, A.D., Farnsworth, N.R., Santisuk, T., 1991, Plant Anticancer Agent, XLVIII. New Cytotoxic Flavonoids from Muntingia calabura roots, J. Nat. Prod., 54, 196-206.

Markham, K. R., 1958, Cara Mengidentifikasi Flavonoid., a. b. Kokasih Padmawinata, ITB, Bandung

Rauf dan Rusdin, 2015, Kimia Pangan, ANDI, Yogyakarta.

Setyowati, W. A. E., Ariani, Ashadi, Bakti, Mulyani, dan Rahmawati, 2014, Skrining Fito kimia dan Identifikasi Komponen Utama Ekstrak Metanol Kulit Durian (Duriozibethinus) Varietas Petruk, Seminar Nasional Kimia dan Pendidikan Kimia, 6, 271-80.

Siti Rahayu, Nunung, K., dan Vina, A., 2015, Ekstraksi dan Identifikasi Senyawa Flavonoid dari Limbah Kulit Bawang Merah sebagai Antioksidan Alami, Skripsi, Jurusan Kimia Fakultas Sains dan Teknologi UIN, Jakarta.

Ukieyanna, Elsha, 2012, Aktivitas Antioksidan, Kadar Fenolik, dan Flavonoid Total Tumbuhan Suruhan (Peperomia pellucida L. Kunth), Skripsi, Fakultas Matematika dan Ilmu Pengetahuan Alam Institut Pertanian Bogor.

Porbowaseso, T. W. B., 2005, Ekstraksi Polifenol Biji Kakao secara Kimiawi Sebagai Antioksidan dan Pewarna Alami. Skripsi,. Jurusan Teknologi Hasil Pertanian, Universitas Jember. 